\title{
SELECTED ONGKAH-ONGKAH OF SAMA DILAUT IN THE PROVINCE OF TAWI-TAWI: THEIR FORMS AND STYLES OF EXPRESSION
}

\author{
Elvinia Reyes- Alivio, Junefe D. Naquira and Josephine M. Lendio \\ College of Education, Mindanao State University-Tawi-Tawi College of Technology and Oceanography,
}

Bongao, Tawi-Tawi, Philippines

\begin{abstract}
This study aimed to determine the forms and style of expression of selected ongkah-ongkah (songs) of SamaDilaut in the province of Tawi-Tawi, the values contained in each song and its influence to the socio-political and economic lives of the SamaDilaut. This study was solely qualitative in nature. The fifteen respondents are from BohehSallang, BongaoPoblacion and Sibutu Municipality where residents are expert in composing folksongs and have been chosen to represent their barangays as contestants in the festivities like: AwwalJamman held during Kamahardikaan sin Tawi-Tawi (Province Day Celebration).
\end{abstract}

\begin{abstract}
Interview method and focused group discussion (FGD) aided by the interview guide and video recorder were used to gather the necessary data. Data were recorded, transcribed, translated from native tongue to English language, analyzed and interpreted to find out the values contained in the songs and how they influenced the socio-economic and political lives of the Sama folks.

This study found out that the common ongkah-ongkah of the SamaDilaut are the tenes-tenes, sangbay, linggisan, lolay, leleng, anakiluh, budjangmanis, pagparinta. Some Sama folksongs like the tenestenes, sangbay, linggisan, pagparinta, anakiluh vary in terms of form and style of expressions, contained repetition of words and rhyming words. Some are also performed through dancing with the accompaniment of stringed instruments like guitar, gitgit and biula (violin), gabbang (bamboo xylophone), reed flute (sawnay) and tambu (drum). It also determined that the ongkah-ongkah contained socio-economic and political values of the SamaDilaut. Through singing they are able to convince people to buy their homemade products like mats (baloy). Some of them were invited to any celebration to perform, thus helping them to earn a living. These songs also provide entertainment to the community folks.
\end{abstract}

Keywords:Ongkah-Ongkah, SamaDilaut, Community Folks, Tenes-Tenes, Gabbang

\section{Introduction}

The folk literature of Muslim cultural communities in Mindanao, Philippines, may be in prose or in verse. But the style and form of expressions may vary from one Muslim cultural community to another with what various languages that people speak. Folk literature follows the oral tradition and that folktales, myths, legends, epic poems, riddles and proverbs are handed down by word of mouth from generation to generation. Moreover, folk literature in the Muslim cultural communities has a participatory audience. The audience listens, reacts and retells what he or she hears to another audience, thereby ensuring the transmission of the folk literary materials to others. Authorship is not individual but it is collective. Basically, the problem that easily comes to mind is the lack of access to the textual materials of these oral genres, if not absenceMost yet to be collected and documented (Asain, 2015).

Spotted throughout the Sulu archipelago and other parts of the Philippines like Mindanao, Visayas and Luzon live the SamaDilaut or Badjaus, Badjau means "man of the seas". By tradition, the people are sea nomads, travelling by boat from one island to the next in search of a fishing harvest

The Sama are highly fragmented people with no overall political unity in terms of government patterned system but have their own political tribal affairs. Specific Sama groups can be distinguished by dialect. However, most identify themselves with a particular island or island cluster.

SamaDilaut traditional songs are handed down orally through generations. The songs are usually sung during marriage celebrations (kandulipagkawin), accompanied by dance (pang-igal) and musical instruments like pulau (flute), gabbang (bamboo xylophone), taunggo' (kulintang gongs), and in modern times, electronic keyboards. There are several types of traditional songs, they include: isun-isun, lunsai, nasid, bua-buaanak, and tinggayun.

Corresponding Author:Elvinia Reyes-Alivio/elviealivio@yahoo.com

$3^{\text {rd }}$ International Conference on Education, 20-22 April 2017, Kuala Lumpur, Malaysia 
Among the more specific examples of SamaDilaut songs are three love songs collectively referred to as Sangbayan. These are DallingDalling, Duldang, and PakiringPakiring. The most well-known of these three is PakiringPakiring (literally "moving the hips")' which is more familiar to the Tausug in its commercialized and modernized form DayangDayang. The Tausug claim that the song is native to their culture, and whether the song is originally Tausug or Sama remain controversial. Most Sama-Dilaut folksongs are becoming extinct, largely due to the waning interest of the younger generations. (https://tobyforreal.wordpress.com/2015/10/21/the-awesome-bajau-tribe/)

According to Bruno (1973), literature is a work of art in which people express the feelings and thought about his society, his fellowmen and his divine creator from the ancient past to the present days. Some of these expressions are in a way to what scholars call oral tradition. This includes folktales, ballads, and folksongs, which passes by word of mouth from generation to generation.

Nettl (2014) in his study on Folk Music said that folk music, type of traditional and generally rural music was originally passed down through families and other small social groups. Typically, folk music, like folk literature, lives in oral tradition; it is learned through hearing rather than reading. It is functional in the sense that it is associated with other activities, and it is primarily rural in origin. The usefulness of the concept varies from culture to culture.

This study aimed to determine the common ongkah-ongkah (songs) of the SamaDilaut in the province of TawiTawi their various forms and styles of expression, the values contained in each song and its influence to the socio-political and economic lives of the people. Specifically, this sought to answer the following questions: 1) What are the common ongkah-ongkah of the SamaDilaut; 2) What are the variations in the ongkah-ongkah in terms of forms and styles of expression.; 3) Which of the ongkah-ongkah contain social, economic and cultural values of the SamaDilaut?; and 4) How do the ongkah-ongkah influence the lives of the Sama folks.

\section{Assumptions}

1. Local folksongs of the SamaDilaut contain socio-economic and cultural values.

2. Sama folksongs influenced the socio-economic and cultural lives of the SamaDilaut.

\section{Significance of the Study}

The result of this study may be of great importance to the English language teachers, students, as well as the future researchers.Collections, recordings and interpretations of folksongs of indigenous people are important to the English language teachers in the ESL classroom and for the students to appreciate the ways of life of local folks. The collection of local folksongs and their interpretations should be included in the ESL curriculum. Preservation of local literature specially those transmitted by words from generation to generation should make part of the literature class for the students to appreciate the culture of the indigenous people through unrecorded songs.

\section{Related Literature}

The Sama have existed in their current territories since before the formation of the Sulu Sultanate. They are related linguistically to the West coast Badjau as well. Second and third generation Sama living in Malaysia may very well be more familiar with the term Bajau than they are with Sama. They still identify themselves with their home island (BadjauUbian, BadjauSimunul, BadjauTabawan) though some have little understanding about their homelands located in the Philippines. Those Sama who have been living in Malaysia for many years as lawful citizens are called BajauPenduduk which in Bahasa Melayu means they are citizens or Lawful residents of Malaysia. The Sama's right to reside in Malaysia must be upheld as there is written accounts of their presence since at least 1770 (Thomas Forrest).

The Sama people can be quite hard to classify. Due to the nomadic nature of the Sama, they can be found in several countries (especially the Philippines, Malaysia and Indonesia). In Malaysia, they are called Badjaus. In the Philippines, other Filipinos call them Badjaos as Samals, depending on which subgroup of the Sama they belong to.

To complicate things further, Sinama is the name for at least four language groups of the Philippines which are then subdivided into numerous dialects depending on what island a person is from. Speakers of Northern Sinama are unaware of these languages names given them by the linguists, because they identify themselves by island and region instead of closeness of language. The SamaDilaut has a tendency to answer questions about 
their identity based on what they believe. SamaDeya, on the other hand, will sometimes classify the SamaDilaut as being completely different from themselves.

The people now live in one of three types of dwellings: Stilt houses on the coast ordinary land houses clustered along protected shorelines or houseboats. Houses that are raised one to three meters above the ground usually consist of a rectangular room with an attached kitchen. Small bridges or planks are connecting houses of the SamaDilaut. Typically, each boat shelter five to six people- a family and maybe one or two other relatives. Two to six families anchor their boats in a cluster while fishing, sharing food and pooling labor and resources.

Philippine folk songs are results of the culture of the Philippines which is highly influenced by history and the blending of foreign persuasions and its indigenous civilization. (www.cebu-philippines.net/philippine-folksongs.html)

Folk music entertains, tells or supports a story, and transmitted from generation to generation. Most often, the songs were obtained through oral tradition, rather in written form, and the singer was left with the task of interpreting the meaning of the lyrics on the basis of his or her cultural milieu. Folk music has been written and performed portraying every theme imaginable. There are love songs and silly songs. There are songs with religious themes and songs with secular lyrics. Folksongs portray the good life and they delineate hardship. (www.encyclopedia.com/topic/Folk_Music.aspx)

According to Bruno (1973), literature is a work of art in which a person expresses his feelings and thoughts about his society, his fellowmen and his divine creator from the ancient past to the present days. Some of these expressions are in a way to what scholars call oral tradition. This includes folktales, ballads, and folksongs, which passes by word of mouth from generation to generation. Nettl (2014) in his study on Folk Music said that folk music, type of traditional and generally rural music was originally passed down through families and other small social groups. Typically, folk music, like folk literature, lives in oral tradition; it is learned through hearing rather than reading. It is functional in the sense that it is associated with other activities, and it is primarily rural in origin. The usefulness of the concept varies from culture to culture.

\section{Related Studies}

Mason (2009) in her folk song and hymn study stressed that "folksongs are a very important part of our cultural heritage because they draw you into the mood of earlier times and help you to better understand the people".

A local researcher, Dumago (1997) studied kata-kata in order to preserve and document the folk narratives. She was able to analyze the idiomatic expression in kata-kata, as a basis for misunderstanding the Tausug language hereby providing insight into their way of life behavior and culture. In her study, she concluded that the katakata, contains themes on peace, loving, struggles and faith in God.

In a study conducted by Sabal (1997) "LANGAN", she discovered that Langan is a song usually sung to soothe the baby to sleep. It is also sang to someone on a journey and during wedding ceremony.

Similar study conducted by Jamma (1993) who found out that the themes of the folksongs among the Sama of TubigSallang centered on sentimentalism, love, livelihood and a will to exist amidst poverty.

The study on Daman by Amilhamja (1998) who stressed that Daman serves as a vehicle of communication in family affairs. It creates lively atmosphere in social gatherings and it is a form of an art expressing verbally human thoughts and feelings with careful and meaningful words. She wrote that Daman does not apply to courtship but it includes conversational words in a friendly relationship.

Meanwhile, Devero (2001) in her study on Sama folksongs concluded that the Sama ways of life lies on their courtship and love affair. Their family upbringing, their religion, belief in the power of the natural phenomena; the way they handle their problems of the heart, the way they love and respect their elders and influence other people to do the same and their belief in the world hereafter are all reflected in their folksongs.

According to Santamaria (2005) in her study entitled "Alter-Lyricism in the SamaLagu-Lagu: Examining the Creative Sources of the Sangbay Song Tribute and Its Relationships with the Igal Dance Tradition", Sangbay expresses its intention and even its character or condition. The "Sangbay" also reveals a conversation between the song and the dance. The Sangbay is "Igal performance-specific" because the singer reflects about his or her song but then he or she eventually relates this to the dancer and the dance. 
Lucero (2003) stressed out that the Sama musical tradition closely relates to those of the other groups in the Sulu area. The oldest musical form, the Luguh is sang in religious and social functions, and has a melancholy tune and slow tempo. The suwah-suwah (sprouting citrus seed) is a sprightly cheerful that accompanies the pangalay dance. The Tenes-Tenes, a relatively recent form is a ballad which is sang on any occasion like fishing, and by anyone, but especially by a young man for his sweetheart. The same melody may be used for different sets of lyrics. Like the Tenes-Tenes, the Leleng is sang on any occasion, by anyone of any age: children at play, a boy teasing a playmate, a youth singing about a faraway sweetheart, a man fishing or resting, but is also sang on special occasions like weddings, haircuts, or circumcisions.

The above mentioned reviews of literature and studies are similar to the present study but different in terms of literary genres, venue, analysis and interpretations.

\section{Methods}

This study was solely qualitative in character. The fifteen respondents are from BohehSallang, BongaoPoblacion and SibutuMunicapality who are experts in composing folksongs and have been chosen to represent their barangays as contestants I the festivities like: AwwalJamman held during Kamahardikaan Sin Tawi-Tawi or Province Day Celebration.

Interview method and focused group discussion (FGD) aided by the interview guide were used to gather data. The recorded data were transcribed, translated from native tongue to English language, analyzed and interpreted to find out the variations of the songs and values that influence the social, political, economic and cultural lives of the Sama folks. Based on the analysis and interpretation of the data, the common ongkah-ongkah of the SamaDilaut are the tenes-tenes, sangbay, linggisan, olay, leleng, anakiluh, budjanganak, pagparinta.

\section{Analysis}

\section{A.Tenes-Tenes}

The word "tenes" has no other literal meaning in Sinama. It refers to a song titled (just like the word "lolay"). The most probable and convincing explanation that the word tenes comes from the name jenes the most popular Sama male singer during the 90's. He together with other singers in the 90's popularized this song using organ. His song has always mentioned when they sang a duet or sangbay (praises). Hence, the word "jenes" evolved into "tenes".

According to SamarindaSalbayani, a resident of Brgy.BoheSallang, tenes-tenes is a song that reminds a person to persevere in life, work hard in order to earn a living (like fishing). Nina Maadil, a resident of BongaoPoblacion, defines tenes-tenes as a song about culture and sang especially during special occasions for recreation. Jumaatiya, 70 years old describes tenes-tenes as an expression of happiness and enjoyment.

\section{B.Linggisan (bird dance)}

Is another song accompanied by a dance called pangalay.Pangalay has a number of versions including the PangalayLinggisan which can be performed by a solo female performer imitating the movement of a bird flight. According to Mr. Rapin-Jairi, Director of the IngatKapandayan Reforming Arts of the Notre Dame of Jolo College, the pangalaylinggisan performed in Sulu characterizes by the graceful movement of the dancer's arms and hands flowing in synchrony the gentle blowing of the wind. While in some other parts of Sulu Archipelago including Tawi-Tawi and Sabah, the movements of arms and hands are more pronounced as they are imitating the waves of Sulu Sea. (pinasmuna.com_ThePangalayDance of Sulu,Aug.31,2013-www.pinasmuna.com2013/8)

\section{C.Sangbay}

According to Matthew Santamaria (2005) who conducted a study on "Alter-Lyricism in the SamaLagu-Lagu; Examining the creative sources of the Sangbay song Tribute and Its Relationships with Igal Dance Tradition",sangbay expresses its intention and even its character or condition. The "Sangbay' is also a conversation between the song and the dance. The sangbay is "igal performance-specific" because the singer reflects about his or her song but then he and she eventually relates this to a dancer and the dance. (journals.upd.edu.ph.article).

Sangbay repertoire consisting of lolai, manismalenggangdalling-dalling among others serve as referents for improvisation performances. A singer pays tribute to the dance by extending the song and by singing with feelings. The dancer repays this tribute to the singer by taking movement cues from the singer and by molding 
the dance performance in certain instances. Sangbay also reveals a conversation between the song and the dance. Sangbay- a Sama genre literature. Sangbay is a tribute song. Just like the Igal, the Sangbay were songs of the Sama titles or labels that were sang in variation by singers while accompanying Igal performed in festivities such as wedding.

\title{
D.Leleng
}

Leleng is sang in any occasion by anyone of any age: children play, boy teasing a playmate, a youth singing about a faraway sweetheart, or man fishing or resting; it also sung on special occasions like weddings, haircuts or circumcision.

Leleng like other ongkah- ongkah is sang with the accompaniment of a string instrument like gitgit and biula, gabbang (a bamboo xylophone) and the kulintangan. (R.C. Lucero, 2003)

In addition, leleng is a song of appreciation. MisiriyaArasani (a resident of BongaoPoblacion) said that it is also used as lullaby-a song that helps mother in taking care of her child. Leleng is also a stress-reliever song especially after work.It teaches us how to persevere in life and not to give up in times of hardships. Leleng is composed and sang depending on the kind of occasion. The SamaDilaut singer can compose at instant a song if requested.

\section{E.AnakIluh}

A kind of lagu-lagu of the SamaDilaut which describes an orphan longing for the love and care of parents. It also describes the hardships and sad experiences of a child of living with relatives and other people. (Fatima Sarmiento, resident of Sibutu).

\section{F.BudjangManis}

A Samaongkah-ongkah that describes the beauty of a maiden, and her unselfish love to a man. It is sometimes sad and happy about reminiscing the past. A Sama singer-composer particularly a woman singer, uses words that describes a lady not only her physical outlook but her inner beauty. (Sahala Miguel, resident of Sibutu)

\section{What are the SamaDilautvariationsin terms of form and style of expressions?}

Most ongkah-ongkah of the SamaDilaut are more of the historical type than lyrical. These are usually sang and arranged in quatrains.

Tenes-tenes is a Samalagu-lagu that describes the way of life of the Sama people (like fishing). The tenes sung by Tullang- a blind singer-composer, describes his life of being an artist where he can earn money out of singing on the public during special occasions like hariraya, paggunting, pagkawin among others. Below is an excerpt of Tullang'stenes-tenes.

\author{
Tenes... teneskinobelansaltahna bay niborda-bordahan \\ Ah... ah... sa bias bias... bang akuitumagkalangkalangan \\ Oy... pakalekalekammgadanakan \\ Pakalekalenakammgadaodanakan oh... minsansuaraitu \\ Lagaw lagawanmasiruakumagsindilsindilan \\ Atiyah eh kusinulaysulayan, oh... \\ Mbalakumagkalagkalangan \\ Bang taentomkumagtundan-tundan \\ Taentumku bay waktujaman \\ Jaman, Jaman bay waktu eh...ey \\ Bay jaman, jamanabasaggihsibaran \\ Oh bang akumagkalangan... \\ Maka eh kunigitar-gitalan \\ Oh daanakam mag-anganangan \\ Oh bang akuitugantamagkalagihaw \\ Day para atoanasibaran...
}




\section{Form:}

Tenes-tenes consists of a four-line stanza called quatrain. It also contains repetition of words found at the beginning and end of the line for instance:

$\begin{array}{ll}\begin{array}{l}\text { borda-bordahan } \\ \text { biasbias }\end{array} & \begin{array}{l}\text { (decorated/made beautiful) } \\ \text { (embarrassing) } \\ \text { magkalangkalangan }\end{array} \\ \begin{array}{l}\text { pakalekale } \\ \text { lagawlagawan }\end{array} & \begin{array}{c}\text { (listening) } \\ \text { (voice of the singer) }\end{array} \\ \text { magsindilsindilan } & \text { (crying/singing) } \\ \text { sinulaysulayan } & \text { (trying) } \\ \text { magtundan-tundan } & \text { (towing/rowing) } \\ \text { jaman, jaman } & \text { (moments) }\end{array}$

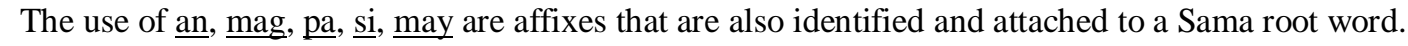

English Translation (Transparency) - translated by Mr. PotchongJackaria

A song that was hidden and made beautiful

Ah... ah it's embarrassing when I'm singing...

Oh listen my brothers and sisters

Listen brothers and sisters, oh... Though my voice

is not beautiful. Here I'm still singing

And keep on trying, oh...

I can't sing

If I remember sailing or rowing boats

I remember the past

Those days were the days... ey

Those days when I was still strong

Every time I sing

And play my guitar

Oh... don't ever dream...

Translation of the song (tenes-tenes) from Sinama (source text) to its English version (target text) was very difficult and tedious. Translation was made first using fidelity (word for word) in order to get the meaning of the song.Analysis was made phrase by phrase then moving on to transparency to get the entire thought of the song. Structure of words was sacrificed deviating from its original form.

\section{Sangbay (Sangbai)}

Is another Samaongkah-ongkah. It is a conversation between the song and a dance. It is a tribute song where the singer pays tribute to the song through a dance - Ma DallinDallin or Igalfor Sama. It is sang with the accompaniment of gabbang (bamboo xylophone), reed flute (sawnay) or tambul (drum) in the absence of gabbang and performed by a male and a female dancer. Below is an excerpt of the song composed by Tullang (the blind singer-composer) paying tribute to his brother Tolsi:

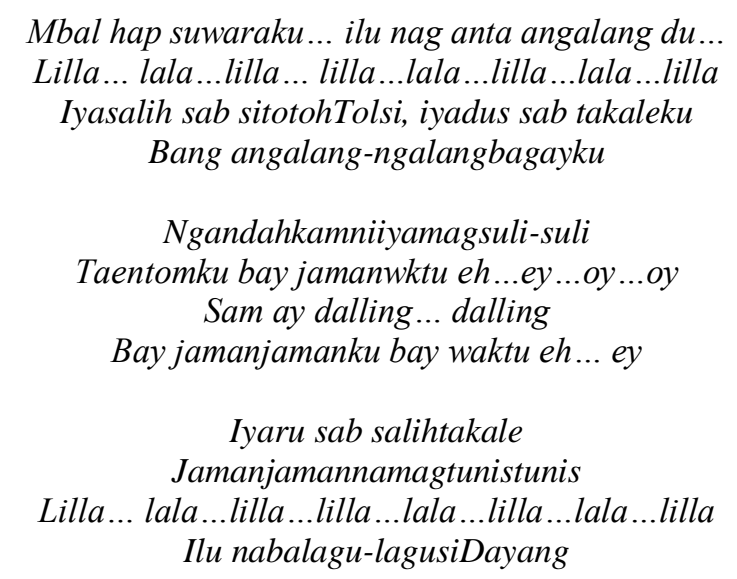


The sangbai by Tullang contains repetition of words for instance: angalang-ngalang (singing); magsuli-suli (telling stories); jaman-jaman (time/hour); magtunis-tunis(singing songs); ongkah-ongkah (songs). Repetition is used perhaps to emphasize the singer's feelings as he sang the Sangbay. Maybe Tullang has been so creative the way he sings and composes his songs. This is compared to the poem written by Robert Frost "Stopping by the Woods on a Snowy Evening" he repeats the last line "and miles to gobefore I sleep, and miles to go before I sleep". Repetition is a literary device that adds meaning to the text - sometimesit is catchy or funny.

English Translation: (translated by PotchongJackaria)

$$
\begin{gathered}
\text { My voice is not that good... but I am still singing } \\
\text { Lilla... lala...lilla... lala ...lilla...lala } \\
\text { And brother Tolsi, I heard him too } \\
\text { If my friend is singing } \\
\text { Look at him telling stories } \\
\text { My darling... darling } \\
\text { Those were my days... hey } \\
\text { I also heard him } \\
\text { During his days singing songs } \\
\text { Here comes the song, baby... }
\end{gathered}
$$

Translation of the song using fidelity and transparency were necessary to get into the thought of the song. The above translation describes the singer himself and his singing voice that is not so beautiful. It also describes his past experience when he was with his brother Tolsi.

\section{AnakIluh}

Is another Samaongkah-ongkah that describes an orphan who was left by his parents and is living with a relative or non-relatives. It also consists of a four-line stanza and the singer-composer observed the use of rhyming words in the song. Below is the lyrics of the song AnakIluhwhicjh was sung by SamarindaSalbayani, a resident of Brgy. BoheSallang.

$$
\begin{gathered}
\text { Naya' miskinantallunganmagdanakan } \\
\text { Dikayuhitu, toongan } \\
\text { DikayuhmopohnangisNapinmihaonggoh } \\
\text { Kahillingsianakiluh } \\
\text { Mikilasiyakamihaiya' usaha } \\
\text { Kapintapakullumnasiyalina } \\
\text { PaddiparasahanmakapanyabotniTuhan } \\
\text { Angeyna the tutu tapamuan } \\
\text { NgamuhNapiniyaniAllahutaala } \\
\text { Kapintapakallumnasiyalina } \\
\text { Kahillingasiyaka "paddiparasahan ta } \\
\text { Susa du bang mbalniyaonggommah ta" }
\end{gathered}
$$

The song AnakIluh contains some rhyming words, for instance:

$$
\begin{aligned}
& \text { magdanakan - toongan } \\
& \text { artasahan ta - mmah ta }
\end{aligned}
$$

English translation (transparency) - translated by Mr. PotchongJackaria

$$
\begin{aligned}
& \text { There were three poor siblings } \\
& \text { One of them, the youngest } \\
& \text { One was crying while washing } \\
& \text { Still longing for their mother }
\end{aligned}
$$


The orphans said

The eldest think of looking for job

So that he can feed his siblings

He felt bad and prayed to the Lord, "Why did He make us like this"

\author{
He still prays to God \\ So that he can feed/sustain his family \\ The eldest said, "I feel bad, \\ It's really hard if we have no parents".
}

The use of rhyming words in this song makes it more pleasant to hear and catchy. It also helps one to easily remember the lyrics of the song.

\title{
BudjangManis
}

A Samaongkah-ongkah that talks about beauty and selfish love. The singer-composer of this song, PagalMelican, resident of Sibutu, also used four-lines for each stanza called quatrain.

Niiyahdanda-dandabudjanglanduhmanis

Maniusnamanisnamanismakatangis

Dandatahahbuun, ungnalanduhpansung

ManismakapunungsiDanda ma-erom

Subulbilahina ma simanismuka
Katisnaaltahnalaepamuwanna
Tudjummahinahmattoajarina

Paggapamuratasigapinangantin

Sigakmanusiyahpabunyugmagkawin

Si lalladayahanmakalanduhhansam

TaabutbinatalansiDandaparagan

Hangkandandalahiniyalallasiddi

Miskinmakalammihbaimagkabilahi

Dandapinihana,.mbal ta tammuna

Taabutngalammalallamonoh di na

Maeromlingkatanasaltagatunang

Makasimiskinanlallalanjang-lanjang

Kaamkapakilannmaksihkamtoongan

Masdigamduwanganmagdikayuhsuratan

There are repetition of words used in this song, it also contains rhyming words, such as;

$$
\begin{gathered}
\text { manis - makatangis } \\
\text { inangantin - magkawin } \\
\text { tunang - lanjang } \\
\text { toongan - suratan }
\end{gathered}
$$

English translation (transparency) - translated by Mr. PotchongJackaria

There was a beautiful maiden who was so beautiful

$$
\text { Her beauty makes one cry }
$$

That maiden with long hair, and high nose 
Elvinia Reyes- Alivio, Junefe D. Naquira and Josephine M. Lendio/Selected Ongkah-Ongkah of SamaDilaut in the Province of Tawi-Tawi: Their Forms and Styles of Expression

Whose beauty can make one unconscious

\author{
A man fell in love with her \\ He has given away everything he has \\ And ask her hand in marriage \\ From the maiden's parents \\ The wedding day came \\ People were happy joining the procession \\ The man was rich and very handsome \\ But just about the final ceremony ends, the bride ran away
}

The reason why she ran away was because of the other man

He was poor and not handsome, but they are in love

He (the fiancée) searched for her but couldn't find her

When he got tired and became hopeless, he committed suicide

The beautiful maiden has a sweetheart

The poor and tall man

Oh, you the religious leaders bear witnesses

The two are meant for each other

The song BudjangManis is translated from Sinama to its English version. Translation was made first using fidelity (word for word) then transparency in order to get the meaning of the song.

The above translation describes the love story of a beautiful maiden who ran away on her wedding day and which tells something about the selfish love the beautiful maiden has. The song also illustrates the simple living of the SamaDilaut and their adherence to traditional practices/ laws. One is the NO intervention of public officials on the arrangement of parents or negotiation between the parents of the woman and the man with regard to marriage. Another is the giving back of the "dowry" to the family of the groom. For the SamaDilaut people, the one who abducted the woman should be responsible to return the dowry (the same amount with the one given to the woman) unlike to that of the other Muslim tribes. These are few of the traditional practices of the SamaDialut which still exist in the present time and are illustrated in the song, BudjangManis.

\title{
Pagparinta
}

Is a Samaongkah-ongkah that talks about politics or governance among the SamaDilautcommunity. The singercomposer, SamarindaSalbayani, resident of Brgy. BoheSallang seldom use rhyming words. There is also no repetition of words in this song.

\author{
Itiyahsinulayannapangissangissahan \\ Na ma kitaminaanmagpartintatoongan \\ Ahekarupanabangsi Mayor bay naan \\ Na he tam pagsukulan \\ Aheka bay pamunanna, murana election \\ Subay heh tam nientomnabinututoongan \\ Si Jasper kohinaannaahekapanabangan \\ Na ahapgihinaaannaehnaamarintanailu bay Makita \\ Mal du takalupa, abinutu heh ta \\ Pasalle ta a taggolnaamarinta \\ Na amuwanankitaaheyapanabangna
}

Some of the rhyming words in this song are:

$$
\begin{gathered}
\text { toongan - naan } \\
\text { ngissahan - naan } \\
\text { toongan - panabangan }
\end{gathered}
$$


heh ta-amarinta

English translation (transparency) - translated by Mr.PotchongJackaria

Here I am trying, as a test

He has been governing us well

The mayor has helped us many times

We should give thanks for it

He has given us many things, and the election is near

We should not forget him and should vote for him

He is Jasper, he has helped us many times

He has led us well

We will not forget him and will vote for him

We should let the one

who has tried to govern

Who always give and help us.

The above translation describes pagparinta or governance as an election campaign song of Mayor Jasper Que written in Sinama dialect.

\section{Which of these Sama folksongs (lagu-lagu) contain socio-economic and cultural values of the SamaDilaut?}

\section{A. Tenes-Tenes}

"Oh listen my brothers and sisters", a line from the song' Tenes-Tenes sung by Tullang( a blind singercompopser), which indicates unity, love, and friendship among SamaDilaut people. It describes the simple living of the SamaDilaut and their engagement in social gatherings (paglami-lamihan). "Here I am retelling the song of ourforefathers" is another line from the song which gives us the idea to value what our forefathers has left for us. Aside from socio-cultural values, Tenes-Tenes also contains economic values, "If I remember sailing or towing boats", which shows that SamaDilaut people are engaged in fishing that serves as their primary source to earn a living. Moreover, SamaDilaut are considered as seafaring people, "I have travelled differentshores", describing their life in the sea, travelling from one place to another.

\section{B. Sangbay}

It is another song accompanied with the dance Igal and a Samalagu-lagu that is sung to give praise and appreciation to other people. The Sangbay sung by SamarindaSalbayani is a song that gives glimpse from the past. "Here I am retelling the story that has a lesson". This indicates that the song contains socio-economic values.

\section{AnakIluh.}

Is another Samaongkah-ongkah which tells a story of an orphan child. This song makes us realized how important family is, and the role of parents in the family. This song contains socio-cultural values since it focuses on the role of the parents, and the family, in general.

"Napinmihaonggohmmah ta", "Susa du bang mbalniyaonggohmmah ta", are lines from the song, AnakIluh, whish support the idea on the importance of parents in the family. These lines indicate a child (Napin) who always look for his parents and find it very hard without their presence. Thus, parents play a very important role in the society.

\section{BudjangManis}

Is another Samaongkah-ongkah which talks about beauty,." Niyahdanda-dandabudjanglanduhmanis". This song tells a story of a beautiful maiden who could melt anybody's heart. BudjangManis is also a song about selfish love "TaabutbinatalansiDandaparagan". The song also tells about the beautiful maiden who ran away with the man whom she loved the most on her wedding day. The second stanza of the song, presents the socio-cultural values. It shows respect for women and obedience of children to parents. 


\author{
Subulbilahina ma simanismuka \\ Katisnaaltahnalaepamuwanna \\ Pagganiyahwaktomahandanaiya \\ Tudjummahinahmattoajarina
}

\title{
E. Pagparinta
}

Is an election campaign song sung by the SamaDialut. The song illustrates an individual asking favor or support from the people for the coming election.

This song, in general, talks about the political life of the people. It gives details on what the person has done for the people so that they will vote for him.

\author{
"He is Jasper, he has helped us many tim[es \\ He has led us well \\ We will not forget him and will vote for him \\ We should let the one who has been tried to govern, give, and help".
}

\section{Findings}

On the basis of the analysis band interpretation of the data gathered, the following are the findings:

The common ongkah-ongkah(folksongs) of the SamaDilaut are Pagparinta, AnakIluh, BudjangManis, TekGoyak, Pila Na Baleleng, Igal-Igal, Duldang, Leleng, Leyang-leyangInah Ku, Tenes-Tenes, andLolay.

Most ongkah-ongkah of the SamaDilaut are more of the historical type than lyrical. These are usually sung and arranged in quatrains. SamaDilaut folksongs vary in terms of style and form of expression. For instance, the Sangbay of Tullang contains repetition of words such as angalang-ngalang (singing); magsuli-suli (telling stories). Repetition is a literary device that adds meaning to the text. It perhapsemphasizes the singer's feelings as he sings the Sangbay. Tenes-tenes is a Samalagu-lagu that describes the way of life of the Sama people (like fishing). It also contains repetition of words found at the beginning and of the line such as borda-bordahan and magkalang-kalangan. However, other Samalagu-lagu have no repeated words used, but contains rhyming words such as manis-tangis. The use of rhyming words catches the attention of the listeners and helps one to remember the lyrics of the song.

Some the SamaDilautongkah-ongkah are performed through dancing with the accompaniment of instruments like gabbang(bamboo xylophone; reed flute (sawnay); or tambul (drum) in the absence of gabbang.

It was also determined in this study that some Samaongkah-ongkah contain socio-economic and cultural values. "Oh, listen my brothers and sisters", A line from the song Tenes-Tenes sung by Tullang, which shows unity, love, and friendship among the SamaDilaut. Aside from socio-cultural values, Tenes-Tenes also contains economic values, "IfI remember sailing or towing boats", which shows that SamaDilaut people are engaged in fishing and it serves as their primary source of living. Sangbay, a tribute song accompanied with dance, also presents socio-cultural values, "Here I am retelling a story that has a lesson".

It was also found out in this study that some Samaongkah-ongkah of the SamaDilaut affect their socio-economic and cultural lives. To them, these songs help them earn a living. Through singing they are able to convince people to buy their products and provide entertainment to the community.

\section{Conclusion}

On the basis of the findings of this study, it is concluded that local folksongs of the SamaDilautvaried terms of forms and styles of expressions. The ongkah-ongkah also contain socio-economic and cultural values and influence the socio-economic and cultural lives of the SamaDilaut.

\section{Recommendations}

Based on the findings and conclusion of this study, the following are hereby recommended: 
The collection of local folksongs and their interpretations should be included in the English Curriculum. Preservation of local literature specifically those transmitted by words from generation to generation should be made part of the lesson in the literature class.

Courses like Asian, European and American literatures offered by the English Department should include folksongs for the students to appreciate the culture of indigenous people and their ways of life through unrecorded songs..Future researchers could also use this study as a reference if they will engage in similar study.

\section{Acknowledgement}

1. Mr. PotchongJackaria- Translator

2. Dr. Forma L. Gonzales- Language Expert, Faculty Researcher and a Faculty of the Language Department

3. Dr. Abduljami S. Ishmael- Sociologist and Faculty of the Social Science Department

4. Dr. Moh'd. MuktarTahil- Faculty, Social Science Department

5. Junefe D. Naquira- Co-Researcher

6. Josephine M. Lendio- Co- Researcher

7. SamaDilaut Residents of Sibutu, BohehSallang and BongaoPoblacion

8. Tullang and Wife- for the songs

9. Prof. Sukinur-ain M. Delasas- Director, Tambuli Dance Troupe

\section{References}

Bruno, Giordano (1973). Literature-IMDb.www.imdb.com>title> literature. Retrieved November 5, 2015.

Bruno, Nettl (2014) Folk and Traditional Music of the Western Continents. Prentice-Hall,Inc.ISBN 0-13323247-6 https://en.m.wikipedia.org>wiki>Bruno... Retrieved December 10,2015

Santamaria Matthew. (2005) Alter-Lyricism in the SamaLagu-Lagu: Examining the Creative Sources of the Sangbay Song Tribute and Its Relationships with the Igal Dance Tradition. UP Diliman Journals Online. Journals.upd.edu.ph>article>viewFile. Retrieved October 16, 2015.

Mason, Charlotte (2009). Folksong and Hymn Study.www.charlottemasonhelp.com>2009/07. Retrieved January 18,2016

Asain, Calbi A. (2015)Folk Literature of the Muslim Cultural Communities. ncca.gov.ph Posted April, 2015. Retrieved December 12,2015

Forrest, Thomas (1969? 1779). Borneo Studies in History, Society and Culture. Edited by Victor T. King, Zawawi Ibrahim, NoorHasharina Hassan. http://books.google.com.ph>books. Retrieved October 22, 2015

(n.d.). Retrieved September 7, 2015, from https://www.allaboutsikhs.com/punjab-the-folk-songs-and-music

(n.d.). Retrieved October 26, 2015, from Copyright 2015 Kawman Sama Online: Sinama Social Network for Sama and Bajau.

(n.d.). Retrieved October 26, 2015, from Folk Literature of the Muslim Cultural Communities-National Commission for Culture and the Arts.

(n.d.). Retrieved October 26, 2015, from www.cebu-philippines.net/philippine-folk-songs.html

(n.d.). Retrieved January 18, 2016, from musicwww.encyclopedia.com/topic/Folk_Music.aspx

(n.d.). Retrieved January 18, 2016, from

www.encyclopediaukraine.com/display.asp?linkpath=pages $\% 5 \mathrm{CF} \% 5 \mathrm{CO} \%$ folksongs.html

(n.d.). Retrieved January 18, 2016, from https://tobyforreal.wordpress.com/2015/10/21/the-awesome-bajau-tribe 
Elvinia Reyes- Alivio, Junefe D. Naquira and Josephine M. Lendio/Selected Ongkah-Ongkah of SamaDilaut in the Province of Tawi-Tawi: Their Forms and Styles of Expression

Encyclopedia American International. (1972).

Amilbangsa. (2012). "Pangalay; Ancient Dance Heritage of Sulu". Retrieved January 24, 2016, from m.inquirer.net/newsinfo/247943

Amilhamja, R. (1998). Daman. Undergraduate Thesis. MSU-TCTO.

Cruz, D. (n.d.). Philippine Folksong and Literature.

Devero. (2001). "Sama Folksongs".

Dumago. (1997). Kata-Kata.

www.cebu-philippines.net/philippine-folk-songs.html)

Mason, C. (n.d.). Retrieved January 23, 2016, from www.charlottemasonhelp.com/2009/07/folk-song-andhymn-study.html?m=1

Nettl, B. (n.d.). Retrieved January 24, 2016, from Folk Music: global.britannica.com/art/folk-music

Sabal. (1997). "LANGAN".

Santamaria. (2005). "Alter-Lyricicsm in the Sama Lagu-Lagu:vExamining the Creative Sources of the Sangbay Song Tribute and Its Relationships with the Igal Dance Traditio".

Thompson, S. (n.d.). Retrieved January 23, 2016, from Folk Literature: www.britannica.com/art/folkliterature/Major-Forms-of-folk-literature 